\title{
Anesthetic quality and cardiovascular and respiratory effects of continuous intravenous infusion of tiletamine-zolazepam in bitches ${ }^{1}$
}

\author{
Sóstenes A.R.S. Pereira ${ }^{2 *}$ (D), Fernanda V. Henrique ${ }^{2}$, Lylian K.G. Medeiros², \\ Janaina K.C. Silva ${ }^{2}$, Arcanjo B. Goes ${ }^{2}$, Antônio F.M. Vaz ${ }^{2}$, Almir P. Souza ${ }^{2}$ \\ and Pedro I. Nóbrega Neto ${ }^{2}$
}

\begin{abstract}
Pereira S.A.R.S., Henrique F.V., Medeiros L.K.G., Silva J.K.C., Goes A.B., Vaz A.F.M., Souza A.P. \& Nóbrega Neto P.I. 2019. Anesthetic quality and cardiovascular and respiratory effects of continuous intravenous infusion of tiletamine-zolazepam in bitches. Pesquisa Veterinária Brasileira 39(3):214-220. Centro de Saúde e Tecnologia Rural, Universidade Federal de Campina Grande, Avenida Universitária s/n, Santa Cecília, Patos, PB 58708-110, Brazil. E-mail: sostenesarthur@bol.com.br

The objective of this study was to evaluate the quality and recovery from anesthesia promoted by the tiletamine-zolazepam (TZ) combination administered intravenously (IV) continuously in bitches pre-medicated with acepromazine. Eight cross-bred, clinically healthy bitches weighing $13.7 \pm 1.9 \mathrm{~kg}$ on average were used in this study. After a food fast of $12 \mathrm{~h}$ and a water fast of four hours, the animals were treated with acepromazine $(0.1 \mathrm{mg} / \mathrm{kg}$, intramuscular) and, after 15 minutes, anesthesia was induced with a combination of tiletamine-zolazepam $(2 \mathrm{mg} / \mathrm{kg}$, IV) immediately followed by continuous IV infusion thereof at a dose of $2 \mathrm{mg} / \mathrm{kg} / \mathrm{h}$ for $60 \mathrm{~min}$. The following parameters were measured in all animals immediately before administration of acepromazine (M15), immediately before anesthetic induction (M0), and at 5, 10, 20, 30, 40, 50, and 60 min after initiation of continuous infusion (M5, M10, M20, M30, M40, M50, and M60): electrocardiography (ECG), heart rate (HR), mean arterial pressure (MAP), respiratory rate (RR), body temperature (BT), and arterial hemogasometry, with the last performed only at experimental times M15, M0, M30, and M60. A subcutaneous electrical stimulator was used to evaluate the degree of analgesia. Myorelaxation and quality of anesthetic recovery were also assessed, classifying these parameters as excellent, good, and poor. Anesthetic recovery time was recorded in minutes. HR increased significantly at time M10 in relation to that at M-15, and at times M5, M10, M40, and M50 in relation to that at M0. MAP decreased significantly at M20 and M30 compared with the baseline. BT decreased significantly at M50 compared with that at M0, but no hypothermia was observed. RR showed significant reduction at M5, $\mathrm{M} 10$, and M20 in relation to that at M-15, and at M5 and M10 in relation to that at M0, and bradypnoea was observed during the first $20 \mathrm{~min}$ after anesthetic induction. Significant decreases in the PR interval at times M10, M40, and M50 were observed in relation to that at M15. Amplitude of the $R$ wave showed significant decrease at M20 compared with that at M-15. In the other ECG parameters, no significant difference was observed between the times evaluated. Hemogasometric parameters and analgesia did not show significant alterations. Myorelaxation and quality of anesthetic recovery were considered excellent. Recovery time was $15.1 \pm 7.7 \mathrm{~min}$ for positioning of sternal decubitus and $45.5 \pm 23.1$ minutes for return of ambulation. Continuous IV administration of TZ combination does not produce satisfactory analgesia and does not cause severe cardiorespiratory and hemogasometric effects in bitches pre-medicated with acepromazine.
\end{abstract}

INDEX TERMS: Anesthetic quality, cardiovascular, respiration, intravenous infusion, tiletamine-zolazepam, bitches, benzodiazepine, dissociative anesthesia, dogs.

${ }^{1}$ Received on September 4, 2018.

Accepted for publication on September 24, 2018.

Master's Research with CAPES support. ${ }^{2}$ Postgraduate Program in Veterinary Medicine,Centro deSaúdee Tecnologia Rural
(CSTR),Universidade Federal de Campina Grande (UFCG), Av.Universitária s/n,Sta.
Cecília,Patos,PB58708-110, Brazil. ${ }^{*}$ Corresponding author: sostenesarthur@bol.com.br 


\section{RESUMO.- [Qualidade anestésica e efeitos cardiovascular e respiratória da infusão intravenosa contínua de tiletamina-zolazepam em cadelas.] Objetivou-se avaliar} a qualidade e a recuperação da anestesia promovida pela associação tiletamina-zolazepam, administrada por via intravenosa (IV) contínua, em cadelas pré-medicadas com acepromazina. Foram utilizadas oito cadelas, sem raças definidas, clinicamente sadias, pesando em média $13,7 \pm 1,9 \mathrm{~kg}$. Após jejum alimentar de 12 horas e hídrico de quatro horas, os animais foram medicados com acepromazina $(0,1 \mathrm{mg} / \mathrm{kg}$, via intramuscular) e, após 15 minutos, a anestesia foi induzida com a associação tiletamina-zolazepam $(2 \mathrm{mg} / \mathrm{kg}$, IV) seguida imediatamente pela infusão IV contínua da mesma, na dose de $2 \mathrm{mg} / \mathrm{kg} / \mathrm{h}$, durante 60 minutos. Os parâmetros que foram mensurados em todos os animais, imediatamente antes da administração da acepromazina (M-15), imediatamente antes da indução anestésica (M0) e, aos 5, 10, 20, 30, 40, 50 e 60 minutos após o início da infusão contínua (M5, M10, M20, M30, M40, M50 e M60) foram os seguintes: eletrocardiografia (ECG), frequência cardíaca (FC), pressão arterial média (PAM), frequência respiratória $(f)$, temperatura corpórea (TC) e hemogasometria arterial, esta sendo realizada apenas nos momentos M-15, M0, M30 e M60. Para avaliação do grau de analgesia foi empregado um estimulador elétrico subcutâneo. Também se avaliou o miorrelaxamento e a qualidade da recuperação anestésica, classificando estes parâmetros em: excelente, bom e ruim. 0 tempo de recuperação anestésica foi registrado em minutos. A FC aumentou significativamente no momento M10 em relação ao M-15, e nos momentos M5, M10, M40 e M50 em relação ao M0. A PAM diminuiu significativamente em M20 e M30 em comparação ao valor basal. A TC diminuiu significativamente em M50 em comparação ao M0, mas não foi observada hipotermia. A $f$ apresentou uma redução significativa nos momentos M5, M10 e M20 em relação ao M-15, e em M5 e M10 em relação ao M0, sendo observado bradipneia durante os primeiros 20 minutos após a indução anestésica. Foram observadas diminuições significativas do intervalo PR nos momentos M10, M40 e M50, em relação ao M-15. A amplitude da onda R apresentou diminuição significativa em M20 em comparação ao M-15. Nos demais parâmetros da ECG não houve diferença significativa entre os momentos avaliados. Os parâmetros hemogasométricos e a analgesia não apresentaram alterações significativas. 0 miorrelaxamento e a qualidade da recuperação anestésica foram considerados excelentes. 0 período de recuperação foi de $15,1 \pm 7,7$ minutos para posicionamento do decúbito esternal e 45,5 $\pm 23,1$ minutos para retorno da deambulação. A administração intravenosa contínua de tiletamina-zolazepam não produz analgesia satisfatória e não causa efeitos cardiorrespiratórios e hemogasométricos severos, em cadelas pré-tratadas com acepromazina.

TERMOS DE INDEXAÇÃO: Qualidade anestésica, cardiovascular, respiratória, infusão intravenosa, tiletamina-zolazepam, cadelas, anestesia dissociativa, benzodiazepínico, cães.

\section{INTRODUCTION}

General intravenous (IV) dissociative anesthesia can be maintained in two ways: repetitive bolus administration and continuous infusion. In both cases, initial IV administration of anesthetic and sedative drugs is required to rapidly create high plasma concentrations of the drugs and enable their rapid arrival to their respective sites of action. When option is made for maintenance of repetitive bolus administration, as drug plasma concentration decreases through the elimination processes, several re-administrations are required to maintain the desired effects; however, this may result in poor maintenance and more frequent undesirable side-effects. Continuous infusion is used to maintain plasma concentrations of one or more drugs in the continuous IV anesthesia technique, and an appropriate infusion rate is needed to maintain a given anesthetic plane, achieve distribution in all tissues, and compensate for the drug elimination processes (Duke 2013).

Among injectable dissociative anesthetics are drugs derived from phencyclidine, characterized by dissociation of the central nervous system (CNS) and causing a change in the state of consciousness. Ketamine hydrochloride (HCL) and tiletamine HCL are the most commonly used dissociative anesthetics in veterinary medicine (Berry 2017), with tiletamine HCL marketed in a fixed proportion combination with zolazepam, and widely used in dissociative anesthesia of dogs, cats, and wild animals. Addition of zolazepam aims to potentiate the effects of tiletamine HCL, promote central-acting myorelaxation, and minimize undesirable side-effects typical of dissociative anesthesia (Lin et al. 1993).

Phenothiazine derived drugs such as acepromazine show tranquilizing, sympatholytic, anxiolytic and antispasmodic action, promoting a calmer anesthetic recovery and potentiation of the anesthesia promoted by the tiletamine-zolazepam (TZ) combination (Almeida et al. 2000, Pereira 2008, Fantoni \& Cortopassi 2014).

Thus, this study aimed to assess the cardiorespiratory effects and the quality and recovery from anesthesia promoted by continuous IV administration of the TZ combination in bitches pre-medicated with acepromazine.

\section{MATERIALS AND METHODS}

This study was approved by the Research Ethics Research Committee of the aforementioned Institution under protocol no. 101-2017.

Eight cross-bred, clinically healthy bitches, weighing $13.7 \pm 1.9 \mathrm{~kg}$ on average, obtained from local breeders, who authorized their participation in the study by signing an Informed Consent Form (ICF), were used in this study. The animals were allocated, individually, in kennels of the Veterinary Hospital for 15 days aiming adaptation, where they were daily provided with fresh water and commercial feed, changed twice a day. Three days prior to the anesthetic procedure, their health status was determined based on physical examination, electrocardiography (ECG), blood count, and biochemical tests (urea, creatinine, alanine aminotransferase, and alkaline phosphatase).

Prior to anesthesia, the animals underwent a food fast of $12 \mathrm{~h}$ and a water fast of four hours (Henrique 2018). After that, trichotomy and antisepsis were performed on the dorsal region of the left forelimb and external face of the left ear for introduction of a $22 \mathrm{G}$ catheter into the cephalic vein for administration of anesthetics and of a $24 \mathrm{G}$ catheter into the auricular artery to measure blood pressure and collect arterial blood samples (Fig.1). Pre-anesthetic medication was performed intramuscularly (IM) with acepromazine at a dose of $0.1 \mathrm{mg} / \mathrm{kg}$ and, after 15 minutes, a TZ combination bolus was administered intravenously (IV) at a dose of $2 \mathrm{mg} / \mathrm{kg}$. Immediately after the bolus administration, continuous IV infusion of these drugs was performed at a rate of $2 \mathrm{mg} / \mathrm{kg} / \mathrm{h}$ for $60 \mathrm{~min}$ using a linear peristaltic infusion pump. Subsequently, the animals were contained in right 


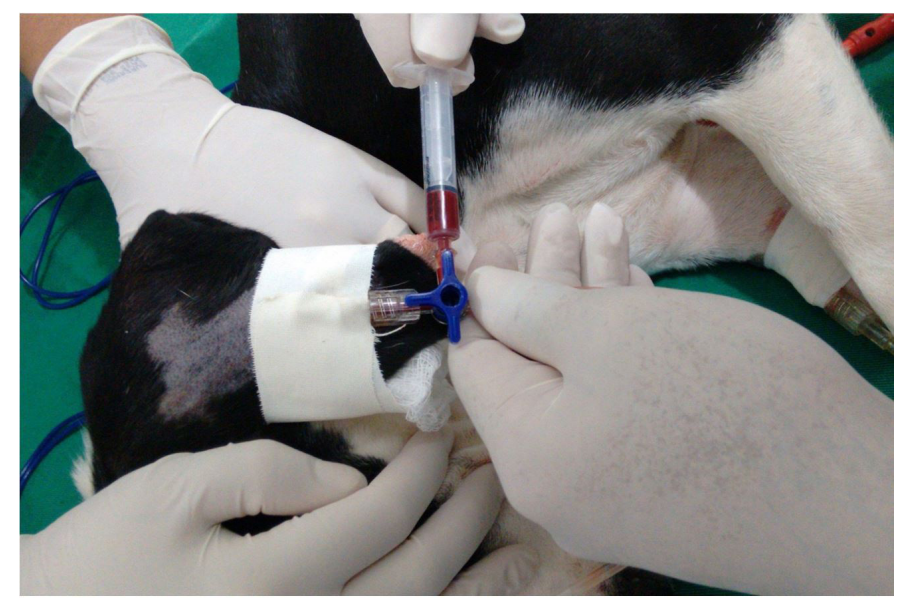

Fig.1. Catheterization of the auricular artery and connection to a 3-way tap for collection of arterial blood samples and measurement of mean arterial pressure (MAP) of bitches pre-medicated with acepromazine and submitted to continuous intravenous (IV) infusion of the tiletamine-zolazepam (TZ) combination.

lateral decubitus on an electric thermal mattress, spontaneously breathing ambient air without endotracheal intubation.

The following parameters were measured in all animals immediately before administration of acepromazine (M15), immediately before anesthetic induction (M0), and at 5, 10, 20, 30, 40, 50, and $60 \mathrm{~min}$ after initiation of continuous infusion (M5, M10, M20, M30, M40, M50, and M60): heart rate (HR), in beats per minute (bpm), obtained by calculation between two $R$ waves, in milliseconds (ms), using a computer-based electrocardiograph machine; mean arterial pressure (MAP), in millimeters of mercury ( $\mathrm{mmHg}$ ), by connecting the catheter inserted into the left atrial artery to an aneroid sphygmomanometer by means of a cannula system filled with heparinized saline solution at a concentration of $10 \mathrm{IU} / \mathrm{mL}$, maintaining the air-solution interface at the height of sternal manubrium; respiratory rate (RR), in movements per minute (mpm), obtained through verification of respiratory movements; body temperature (BT), in Celsius degrees $\left({ }^{\circ} \mathrm{C}\right)$, obtained by maintaining the sensor of the multi-parametric monitor in contact with the rectal mucosa; electrocardiography (ECG), using a computer-based ECG machine, obtaining, in milliseconds ( $\mathrm{ms}$ ) or millivolts $(\mathrm{mV})$, the values referring to the duration and amplitude of the $P$ wave ( $P$ ms and $P m V$ ), duration of the QRS complex (QRSms), amplitude of the $R$ wave $(R \mathrm{mV})$, duration of intervals between the $Q$ and $T$ waves (QTms) and between the $P$ and $R$ waves (PRms), in addition to search of peaked $T$ waves, ST segment infra-unlevelling, abnormal electrocardiographic figures, and cardiac arrhythmias. The skin electrodes were placed in the humeral-radio-ulnar and femoro-tibial-patellar joint regions. ECG monitoring was performed throughout the anesthetic procedure and, at each experimental time (M), ECG recording was conducted for $30 \mathrm{~s}$ for further observation and measurement of the respective waves.

Arterial hemogasometry was also assessed, measuring the following values at experimental times M15, M0, M30, and M60: potential of hydrogen ion $(\mathrm{pH})$; partial pressure of arterial oxygen $\left(\mathrm{PaO}_{2}\right)$, in mmHg; partial pressure of carbon dioxide $\left(\mathrm{PaCO}_{2}\right)$, in $\mathrm{mmHg}$; total carbon dioxide $\left(\mathrm{TCO}_{2}\right)$ in plasma, in millimole per liter $(\mathrm{mmol} / \mathrm{L})$; arterial oxyhemoglobin saturation $\left(\mathrm{SaO}_{2}\right)$, in percentage (\%); bicarbonate $\left(\mathrm{HCO}_{3}^{-}\right)$, in milliequivalents per liter $(\mathrm{mEq} / \mathrm{L})$; base excess (BE), in $\mathrm{mEq} / \mathrm{L}$, through collection of $0.5 \mathrm{~mL}$ of whole blood in dry electrolyte-balanced heparinized syringes and immediate hemogasometric analysis. All blood gas values were corrected according to body temperature, recorded at the time of sampling.

Degree of analgesia was assessed according to a methodology adapted from Figueiró et al. (2016), using an electrical stimulator connected to a pair of stainless steel needles spaced by $3 \mathrm{~cm}$ and subcutaneously inserted into the tail ventral base. Each stimulus was applied by increasing the constant current (in mA) until a positive response was observed. Any movement of the head or limbs, occurred during stimulation, was considered a positive response. Three observers evaluated the response by direct visual observation. In case of disagreement between the observers, the response was discarded and the stimulus was repeated. Analgesia was monitored only as of the beginning of continuous infusion of the TZ combination (form times M5 to M60) considering that electrical stimulation in dogs is an alternative to the supramaximal mechanical noxious stimulation through tail-base clamp (Yamashiro et al. 2015). Thus, current intensities $\geq 30 \mathrm{~mA}$ are considered supramaximal noxious stimuli for the same anatomical site in the tail (Figueiró et al. 2016)

Myorelaxation was evaluated based on the degree of extensor rigidity and resistance of the limbs to manipulation and on muscle tone; this parameter was rated as follows: excellent (score 2), when total muscle flaccidity was evident; good (score 1), when moderate maintenance of muscle tone was observed, with occurrence of discrete tremors; poor (score 0), if the animal showed tremors and stiffness, state of catalepsy, or intense movement. The quality of recovery after anesthesia was evaluated according to the following scores: excellent (score 2), when the animal rested quietly, but responsively; good (score 1), when the animal showed moderate excitement; poor (score 0), when it showed agitation, tremors and/or myoclonus (Cardoso et al. 2008). Anesthesia recovery time was recorded in minutes, comprising the time elapsed between end of continuous infusion and beginning of spontaneous ambulation, also recording the time that the animal assumed sternal decubitus. Manifestations of undesirable side-effects such as vocalization, tremors, escape behavior and/or excitement, vomiting, and defecation were verified.

Statistical analysis of the data was performed using the BioEstat 5.0 software at $5 \%$ significance level $(p<0.05)$. Analysis of variance (ANOVA) was used for the repeated samples, followed by the Tukey test (parametric distribution) or the Friedman test (non-parametric distribution) to verify variation between the experimental times.

\section{RESULTS AND DISCUSSION}

Heart rate (HR) showed significant increase at experimental time M10 compared with that at M15, as well as at times M5, M10, M40, and M50 compared with that at M0 (Table 1). Possibly, the increase observed after administration of the tiletamine-zolazepam (TZ) combination was due to the sympathomimetic action of tiletamine, which increases $\mathrm{HR}$, a characteristic common to dissociative agents well documented in the literature (Almeida et al. 2000, Mello \& Cordeiro 2001, Valadão \& Pacchini 2001, Pereira 2008, Valadão 2011, Berry 2017).

Mean arterial pressure (MAP) was significantly reduced at times M20 and M30 compared with that at M15 (Table 1). The decrease in MAP observed after administration of preanesthetic medication was probably due to the effect of acepromazine. Considering normal values of MAP from 80 to $120 \mathrm{mmHg}$, this decrease led to a condition of mild hypotension, well above the threshold at which hypotension is considered severe $-60 \mathrm{mmHg}$ (Haskins 2017). The reduction 
observed at 20 and 30 min of continuous infusion of the $\mathrm{TZ}$ combination was possibly potentiated by the action of zolazepam, which may induce tachycardia and decreased blood pressure, which is not observed when tiletamine is administered alone, because it increases HR and MAP (Lin et al. 1993). However, even with the use of the TZ combination, the dose of tiletamine administered could not surpass the hypotensive effect of acepromazine. Pereira (2008) performed intravenous (IV) administration of tiletamine-zolazepam $(3 \mathrm{mg} / \mathrm{kg})$ in bitches pre-medicated with levomepromazine (1mg/kg) and did not observe decreased MAP; however, levomepromazine is a phenothiazine much less hypotensive than acepromazine (Fantoni \& Cortopassi 2014). In addition, the values observed in the present study normalized immediately after interruption of the TZ combination infusion probably because of the shorter action duration of zolazepam compared with that of tiletamine (Berry 2017).

Table 1. Mean \pm standard deviation of mean arterial pressure (MAP), in $\mathrm{mmHg}$, and median \pm interquartile deviation of heart rate (HR), in bpm, body temperature (BT), in ${ }^{\circ} \mathrm{C}$, and respiratory rate (RR), in mpm of bitches pre-medicated with acepromazine and submitted to continuous IV infusion of the TZ combination

\begin{tabular}{|c|c|c|c|c|}
\hline \multirow{2}{*}{$\begin{array}{c}\text { Experimental } \\
\text { times }\end{array}$} & \multicolumn{4}{|c|}{ Parameters } \\
\hline & MAP & HR & $\mathrm{BT}$ & $f$ \\
\hline M15 & $89.5^{A} \pm 9.7$ & $106.0^{\mathrm{AC}} \pm 26.3$ & $38.9^{\mathrm{AB}} \pm 0.5$ & $41.0^{\mathrm{A}} \pm 6.5$ \\
\hline M0 & $76.4^{\mathrm{AB}} \pm 8.2$ & $98.5^{A} \pm 10.3$ & $38.5^{\mathrm{A}} \pm 0.4$ & $36.0^{\mathrm{AC}} \pm 14.5$ \\
\hline M5 & $75.0^{\mathrm{AB}} \pm 6.1$ & $133.5^{\mathrm{BC}} \pm 19.5$ & $38.2^{\mathrm{AB}} \pm 1.3$ & $15.0^{\mathrm{B}} \pm 9.3$ \\
\hline M10 & $75.0^{\mathrm{AB}} \pm 9.2$ & $130.5^{\mathrm{B}} \pm 19.3$ & $38.1^{\mathrm{AB}} \pm 1.2$ & $16.0^{\mathrm{B}} \pm 8.8$ \\
\hline M20 & $72.3^{\mathrm{B}} \pm 11.7$ & $124.0^{\mathrm{ABC}} \pm 27.3$ & $37.8^{\mathrm{AB}} \pm 1.2$ & $16.0^{\mathrm{BC}} \pm 9.0$ \\
\hline M30 & $72.0^{\mathrm{B}} \pm 5.7$ & $124.5^{\mathrm{ABC}} \pm 49.3$ & $37.7^{\mathrm{AB}} \pm 1.3$ & $22.0^{\mathrm{ABC}} \pm 19.8$ \\
\hline M40 & $77.3^{\mathrm{AB}} \pm 13.7$ & $121.5^{\mathrm{BC}} \pm 53.3$ & $37.7^{\mathrm{AB}} \pm 1.6$ & $28.0^{\mathrm{ABC}} \pm 13.0$ \\
\hline M50 & $79.3^{\mathrm{AB}} \pm 13.9$ & $145.0^{\mathrm{BC}} \pm 43.0$ & $37.6^{\mathrm{B}} \pm 1.6$ & $28.0^{\mathrm{ABC}} \pm 14.0$ \\
\hline M60 & $83.5^{\mathrm{AB}} \pm 15.8$ & $125.0^{\mathrm{ABC}} \pm 49.8$ & $37.7^{\mathrm{AB}} \pm 1.5$ & $23.0^{\mathrm{ABC}} \pm 14.0$ \\
\hline
\end{tabular}

A significant decrease in body temperature (BT) was observed at experimental time M50 compared with that at M0 (Table 1). The TZ combination promotes depressant effect on the temperature of dogs (Veado 2001, Mello \& Cordeiro 2001), and its association with phenothiazines may potentiate depression of the thermoregulatory center (Almeida et al. 2000, Pereira 2008, Lacerda et al. 2010). However, in disagreement with the hypothermia reported by other authors, BT remained within the physiological limits $\left(37.5-39.2^{\circ} \mathrm{C}\right)$ at all experimental times assessed (Feitosa 2014) because of the heat provided by the thermal mattress throughout the experimental period, which aimed to minimize temperature decrease. Under these conditions, the protocol employed did not interfere physiologically with BT.

Respiratory rate (RR) was significantly reduced at times M5, M10, and M20 in relation to that at M-15, and at M5 and M10 compared with that at M0 (Table 1). The mean values of RR remained below the reference values for the species, from 18 to $36 \mathrm{mpm}$ (Feitosa 2014), during the first $20 \mathrm{~min}$ after anesthetic induction. According to Valadão \& Pacchini (2001), the TZ combination produces transient respiratory depression immediately after IV administration. In addition, it gives rise to an apneustic respiratory pattern characterized by deep breathing with irregular frequency and prolonged pauses (Berry 2017), similar to that observed in the present study. It is worth noting that tachypnea was observed at the mean baseline value, but an upper limit normal RR value was observed at MO, possibly, caused by the stress of pre-anesthetic manipulation.

The ECG parameters evaluated at all experimental times (Table 2) showed mean values within the reference limits for the species: $P$ ms from 40 to $50 \mathrm{~ms}, P \mathrm{mV}$ up to $0.4 \mathrm{mV}$, PRms from 60 to $130 \mathrm{~ms}, \mathrm{QRSms}$ up to $60 \mathrm{~ms}, \mathrm{RmV}$ up to $3 \mathrm{mV}$, e QTms ranging from 150 to 250ms (Goodwin 2002). Therefore, the drugs under test did not alter the electrical conduction of the heart. ECG tracing did not show changes in HR during the experimental period, only confirmed a more accentuated HR increase after administration of the TZ combination. Similar results were reported by Pereira (2008) after IV administration of the TZ combination in bitches pre-medicated with levomepromazine.

Table 2. Median \pm interquartile deviation of duration of the $P$ wave (Pms - milliseconds) and mean \pm standard deviation of amplitude the $P$ wave (PmV - millivolts), duration of the PR interval (PRms - milliseconds), duration of the QRS complex (QRSms - milliseconds), amplitude of the $R$ wave ( $R \mathrm{mV}$ - millivolts) and of the QT interval (QTms - milliseconds) of bitches pre-medicated with acepromazine and submitted to continuous IV infusion of the TZ combination

\begin{tabular}{|c|c|c|c|c|c|c|}
\hline \multirow{2}{*}{ Experimental times } & \multicolumn{6}{|c|}{ Parameters } \\
\hline & $P$ ms & $P m V$ & PRms & QRSms & $R \mathrm{mV}$ & QTms \\
\hline M15 & $44^{\mathrm{A}} \pm 4$ & $0.19^{\mathrm{A}} \pm 0.04$ & $105.8^{A} \pm 12.6$ & $40.5^{A} \pm 3.3$ & $1.01^{\mathrm{A}} \pm 0.41$ & $208.0^{A} \pm 23.8$ \\
\hline M0 & $44^{\mathrm{A}} \pm 4$ & $0.18^{\mathrm{A}} \pm 0.05$ & $103.0^{\mathrm{AB}} \pm 14.5$ & $40.5^{A} \pm 3.3$ & $0.93^{\mathrm{AB}} \pm 0.35$ & $224.5^{\mathrm{A}} \pm 18.8$ \\
\hline M5 & $44^{\mathrm{A}} \pm 1$ & $0.21^{\mathrm{A}} \pm 0.07$ & $92.0^{\mathrm{AB}} \pm 7.1$ & $40.0^{A} \pm 3.0$ & $0.79^{\mathrm{AB}} \pm 0.35$ & $207.5^{\mathrm{A}} \pm 22.0$ \\
\hline M10 & $40^{\mathrm{A}} \pm 5$ & $0.21^{\mathrm{A}} \pm 0.07$ & $89.5^{\mathrm{B}} \pm 8.3$ & $40.5^{A} \pm 3.3$ & $0.78^{\mathrm{AB}} \pm 0.35$ & $208.0^{A} \pm 19.6$ \\
\hline M20 & $40^{\mathrm{A}} \pm 1$ & $0.20^{A} \pm 0.08$ & $92.5^{\mathrm{AB}} \pm 9.2$ & $40.0^{A} \pm 3.0$ & $0.76^{\mathrm{B}} \pm 0.37$ & $214.5^{\mathrm{A}} \pm 21.5$ \\
\hline M30 & $42^{\mathrm{A}} \pm 5$ & $0.22^{\mathrm{A}} \pm 0.08$ & $90.0^{\mathrm{AB}} \pm 14.8$ & $39.5^{A} \pm 3.3$ & $0.86^{\mathrm{AB}} \pm 0.38$ & $204.0^{A} \pm 27.1$ \\
\hline M40 & $44^{\mathrm{A}} \pm 5$ & $0.23^{\mathrm{A}} \pm 0.07$ & $89.0^{\mathrm{B}} \pm 14.5$ & $41.0^{\mathrm{A}} \pm 4.1$ & $0.90^{\mathrm{AB}} \pm 0.36$ & $208.5^{\mathrm{A}} \pm 24.0$ \\
\hline M50 & $44^{\mathrm{A}} \pm 8$ & $0.28^{A} \pm 0.12$ & $89.0^{\mathrm{B}} \pm 16.5$ & $40.0^{A} \pm 3.0$ & $0.89^{\mathrm{AB}} \pm 0.33$ & $208.0^{A} \pm 23.9$ \\
\hline M60 & $42^{\mathrm{A}} \pm 5$ & $0.22^{A} \pm 0.08$ & $95.0^{\mathrm{AB}} \pm 17.9$ & $41.5^{A} \pm 3.7$ & $0.95^{\mathrm{AB}} \pm 0.35$ & $210.0^{A} \pm 42.7$ \\
\hline
\end{tabular}

$\overline{\mathrm{A}, \mathrm{B}, \mathrm{AB}}$ Means followed by different letters in the same column differ statistically between experimental times. 
HR is inversely proportional to the duration of the PR interval, so that the intervals are short in tachycardia and long in bradycardia (Filippi 2011). Similar results were observed in the present study during the times of increased $\mathrm{HR}$, with a significant decrease in the PR interval at times M10, M40, and M50 in relation to that at M15 (Table 2). In addition, the amplitude of the $R$ wave showed a significant decrease at time M20 compared with that at M15 (Table 2); however, it is not indicative of change in ventricular activation because there is no minimum height for the $R$ wave (Filippi 2011).

None of the hemogasometric parameters assessed varied significantly throughout the experiment (Table 3). Normally, atmospheric oxygen is vented in the alveoli and then diffuses through the respiratory membrane along partial pressure gradients in the plasma. Partial pressure of arterial oxygen $\left(\mathrm{PaO}_{2}\right)$ is a measure of the lung capacity to transport oxygen from the atmosphere to the blood, and its normal values for dogs spontaneously breathing ambient air vary from 80 to $110 \mathrm{mmHg}$. In general, hypoxemia occurs for values of $\mathrm{PaO}_{2}<80 \mathrm{mmHg}$ and of arterial oxyhemoglobin saturation $\left(\mathrm{SaO}_{2}\right)^{2}<90 \%$ (Haskins 2017). In view of that, it can be stated that the anesthetic protocol employed did not promote hypoxemia, because all means remained within the thresholds for the species (Table 3). $\mathrm{PaCO}_{2}$ usually ranges from 35 to $45 \mathrm{mmHg}$. $\mathrm{PaCO}_{2}$ values $>60 \mathrm{mmHg}$ may be associated with excessive respiratory acidosis and, in general, it is considered representative of hypoventilation, whereas $\mathrm{PaCO}_{2}$ values $<20 \mathrm{mmHg}$ are associated with respiratory alkalosis (Haskins 2017). In this study, considering the standard deviation, at experimental times $\mathrm{M} 0$ and $\mathrm{M} 30, \mathrm{PaCO}_{2}$ values below normality for the species of 32.5 and $32.7 \mathrm{mmHg}$ were observed; however, this variable was normalized at M60, where similarly to the baseline, remained within the reference values without any evidence of respiratory acidosis or alkalosis (Table 3). It is likely that the respiratory pattern, characterized by deep breathing, and the significant decrease in BT during the experiment may have contributed to the greater elimination and lower production of carbon dioxide, respectively, at the initial times after continuous infusion (M0 and M30). In addition, a tachypneic baseline RR mean value was observed, which may temporarily induce decreased $\mathrm{PaCO}_{2}$, with subsequent increase at M60.

The mean values of bicarbonate $\left(\mathrm{HCO}_{3}^{-}\right)$and total carbon dioxide $\left(\mathrm{TCO}_{2}\right)$ remained within the physiological standards for canines, from 17.2 to $23.0 \mathrm{mEq} / \mathrm{L}$ and 18.0 to $24.1 \mathrm{mmol} / \mathrm{L}$, respectively (Table 3 ). However, considering the standard deviation, the $\mathrm{HCO}_{3}^{-}$values were below normality for the species $(16.2 \mathrm{mEq} / \mathrm{L}$ at M0 and $17 \mathrm{mEq} / \mathrm{L}$ at M60). Arterial potential of hydrogen ion $(\mathrm{pH})$ at experimental time M60 declined to a value smaller than the reference range for the species (7.36-7.44) (Vanova-Uhrikova et al. 2017) (Table 3). This experimental time showed coincidence between the highest and lowest $\mathrm{PaCO}_{2}$ and $\mathrm{HCO}_{3}^{-}$values found, respectively, and although no statistical significance was observed, the higher $\mathrm{PaCO}_{2}$ value probably activated compensatory mechanisms of $\mathrm{HCO}_{3}^{-}$reduction. In contrast, base excess (BE), which is also calculated from $\mathrm{HCO}_{3}$; , showed a mean value below that considered normal for dogs (from -5.5 to $-0.9 \mathrm{mEq} / \mathrm{L}$ ) at M60 (Table 3), characterizing a condition of metabolic acidosis (Vanova-Uhrikova et al. 2017), which may have influenced the changes observed in $\mathrm{pH}$ values. These findings were similar to those reported by Pereira (2008), who observed a decrease in $\mathrm{pH}$ and $\mathrm{BE}$, with values below normality, detecting lower mean values 45 minutes after IV administration of the TZ combination, but this was considered a disorder usually corrected without the need for alkalizing substances. Possibly, the reported changes resulted from respiratory depression caused by the drugs used and, therefore, systemic compensatory mechanisms were activated (Savvas et al. 2005).

Evaluation of the degree of analgesia showed no significant difference between the experimental times regarding the intensity of milliamperage needed to produce response to electrical stimuli (RES) (Table 4). However, the protocol used in this study did not provide sufficient analgesia to block response to the supramaximal noxious stimuli. Thus, to obtain satisfactory analgesia, association of analgesic drugs and/or local blockades with the present protocol and/or increased anesthetic maintenance dose are indicated.

Table 3. Median \pm interquartile deviation of the potential of hydrogen ion $(\mathrm{pH})$, partial pressure of arterial oxygen

$\left(\mathrm{PaO}_{2}\right)$, in $\mathrm{mmHg}$, partial pressure of carbon dioxide $\left(\mathrm{PaCO}_{2}\right)$, in $\mathrm{mmHg}$, bicarbonate $\left(\mathrm{HCO}_{3}{ }^{-}\right)$, in $\mathrm{mEq} / \mathrm{L}$, arterial oxyhemoglobin saturation $\left(\mathrm{SaO}_{2}\right)$, in \%, and total carbon dioxide $\left(\mathrm{TCO}_{2}\right)$ in plasma, in $\mathrm{mmol} / \mathrm{L}$, and mean \pm standard deviation of base excess (BE), in $\mathrm{mEq} / \mathrm{L}$ of bitches pre-medicated with acepromazine and submitted to continuous IV infusion of the TZ combination

\begin{tabular}{lcccc}
\hline \multirow{2}{*}{ Parameters } & \multicolumn{4}{c}{ Experimental times } \\
\cline { 2 - 5 } & $\mathrm{M}-15$ & $\mathrm{M} 0$ & $\mathrm{M} 30$ & $\mathrm{M} 60$ \\
\hline $\mathrm{pH}$ & $7.37^{\mathrm{A}} \pm 0.04$ & $7.38^{\mathrm{A}} \pm 0.08$ & $7.39^{\mathrm{A}} \pm 0.07$ & $7.27^{\mathrm{A}} \pm 0.09$ \\
$\mathrm{PaO}_{2}$ & $100.5^{\mathrm{A}} \pm 8.0$ & $101.0^{\mathrm{A}} \pm 3.3$ & $98.0^{\mathrm{A}} \pm 9.0$ & $100.0^{\mathrm{A}} \pm 4.5$ \\
$\mathrm{PaCO}_{2}$ & $40.5^{\mathrm{A}} \pm 3.3$ & $37.5^{\mathrm{A}} \pm 5.0$ & $35.5^{\mathrm{A}} \pm 2.8$ & $41.0^{\mathrm{A}} \pm 3.0$ \\
$\mathrm{HCO}_{3}^{-}$ & $21.5^{\mathrm{A}} \pm 2.5$ & $20.5^{\mathrm{A}} \pm 4.3$ & $21.5^{\mathrm{A}} \pm 3.3$ & $18.5^{\mathrm{A}} \pm 1.5$ \\
$\mathrm{SaO}_{2}$ & $96.0^{\mathrm{A}} \pm 1.5$ & $95.5^{\mathrm{A}} \pm 2.5$ & $96.0^{\mathrm{A}} \pm 1.0$ & $95.5^{\mathrm{A}} \pm 2.0$ \\
$\mathrm{TCO}_{2}$ & $22.5^{\mathrm{A}} \pm 2.5$ & $21.5^{\mathrm{A}} \pm 4.3$ & $22.5^{\mathrm{A}} \pm 3.3$ & $19.5^{\mathrm{A}} \pm 1.5$ \\
$\mathrm{BE}$ & $-3.6^{\mathrm{A}} \pm 3.3$ & $-3.1^{\mathrm{A}} \pm 4.5$ & $-1.8^{\mathrm{A}} \pm 2.8$ & $-7.6^{\mathrm{A}} \pm 3.3$
\end{tabular}

A Means followed by different letters in the same column differ statistically between experimental times.

Table 4. Median \pm interquartile deviation of myorelaxation (Myo), in scores, and response to electrical stimuli (RES), in milliamperes, of bitches pre-medicated with acepromazine and submitted to continuous IV infusion of the TZ combination

\begin{tabular}{ccc}
\hline \multirow{2}{*}{ Experimental times } & \multicolumn{2}{c}{ Parameters } \\
\cline { 2 - 3 } M0 & RES & Myo \\
\hline M5 & - & $0.5^{\mathrm{A}} \pm 1.0$ \\
M10 & $20.0^{\mathrm{A}} \pm 4.6$ & $2.0^{\mathrm{B}} \pm 0.0$ \\
M20 & $20.0^{\mathrm{A}} \pm 4.6$ & $2.0^{\mathrm{B}} \pm 0.0$ \\
M30 & $21.3^{\mathrm{A}} \pm 4.4$ & $2.0^{\mathrm{B}} \pm 0.0$ \\
M40 & $20.0^{\mathrm{A}} \pm 7.1$ & $2.0^{\mathrm{AB}} \pm 0.3$ \\
M50 & $21.9^{\mathrm{A}} \pm 7.5$ & $2.0^{\mathrm{AB}} \pm 1.0$ \\
M60 & $21.3^{\mathrm{A}} \pm 5.8$ & $2.0^{\mathrm{AB}} \pm 1.0$ \\
& $15.6^{\mathrm{A}} \pm 7.3$ & $1.5^{\mathrm{AB}} \pm 1.0$
\end{tabular}

A, B, AB Means followed by different letters in the same column differ statistically between experimental times. 
At experimental time M0, half of the bitches showed good myorelaxant scores and half of them presented poor scores; at times M5, M10, and M20,100\% of the animals showed excellent scores; at M30, 75\% had excellent scores and 25\% showed good scores; at M40, 62.5\% presented excellent scores and $37.5 \%$ showed good scores; at M50, 62,5, 25, 12.5\% of the canines showed excellent, good and poor scores, respectively; at M60, 50, 37.5, and $12.5 \%$ had excellent, good and poor scores, respectively. Muscle relaxation increased at times M5, M10, and M20 compared with the values observed after administration of acepromazine (Table 4), which was expected after induction and anesthetic maintenance with a central acting myorelaxant - benzodiazepine zolazepam (Valadão 2011). The myorelaxation observed at these times was classified as excellent due to the deeper "sleep state" observed after anesthetic induction (Mello \& Cordeiro 2001) and beginning of the anesthetic infusion; however, from time M30, excellent myorelaxation was maintained in only $50 \%$ of the animals throughout experimental period, whereas a gradual reduction was observed in the other half, and these animals would possibly need an increase in the anesthetic maintenance rate.

As of 20 minutes of infusion, tongue movements, nystagmus and salivation were observed in six, two and three bitches, respectively, which are characteristics typical of dissociative anesthesia (Valadão 2011); they disappeared $40 \mathrm{~min}$ after the beginning of infusion. Two animals showed movement of the pelvic limbs 50 min after infusion; these were the youngest animals in the group - aged six months to one year, and which would probably demand a higher infusion rate.

The quality scores of recovery after anesthesia were classified as excellent in seven bitches and as good in only one, which shows a slight scape behavior; even so, no changes were observed during this period. In canines, the action duration of tiletamine is longer than that of zolazepam. This means that effects typical of dissociative anesthetics are expected during recovery, including muscle stiffness, sympathetic stimulation, and emergency delirium; therefore, association with other drugs such as phenothiazines is necessary (Berry 2017). The use of acepromazine associated with the TZ combination provides prolonged anesthesia period and calmer recovery with less intense muscle tremors (Almeida et al. 2000). However, no tremors were observed during the recovery period. Anesthesia recovery time was $15.1 \pm 7.7 \mathrm{~min}$ for positioning of sternal decubitus and $45.5 \pm 23.1 \mathrm{~min}$ for return of ambulation. Mello \& Cordeiro (2001) performed IV administration of $6.6 \mathrm{mg} / \mathrm{kg}$ of the TZ combination in adult dogs and observed mean times of $101.6 \pm 11.4 \mathrm{~min}$ for positioning of sternal decubitus and $130.7 \pm 11.38 \mathrm{~min}$ for return of ambulation - times recorded as of intramuscular (IM) administration. If we subtract $60 \mathrm{~min}$ from these times, which was the infusion time in this study, these values are still greater, with 41.6 min for positioning of sternal decubitus and $70.7 \mathrm{~min}$ for return of ambulation, demonstrating that a bolus of $2 \mathrm{mg} / \mathrm{kg}$ and a maintenance rate of $2 \mathrm{mg} / \mathrm{kg} / \mathrm{h}$ for $60 \mathrm{~min}$ of the TZ combination do not prolong anesthesia recovery time compared with IM administration. It is worth mentioning that, in the present study, the animals were pre-medicated with acepromazine, which interferes with anesthesia recovery time. Almeida et al. (2000) assessed the $\mathrm{TZ}$ combination $(10 \mathrm{mg} / \mathrm{kg})$ in dogs pre-medicated or not with acepromazine $(0.2 \mathrm{mg} / \mathrm{kg})$, both intravenously, and observed that, after 60 minutes, when the animals were untied from the table and placed on the floor, two of them that had not received acepromazine remained in sternal decubitus, eight were in quadruped position and, of these, two returned to ambulation; whereas of those that had received acepromazine, only one was able to remain in quadruped position while the others remained in sternal decubitus. Continuous infusion provides maintenance of constant plasma levels, prolonging the anesthesia period with faster recovery, when the anesthetics used do not have a cumulative effect, reducing the consumption of IV anesthetic agents by 25-30\%, as well as presenting lower incidence of side effects (Mannarino 2002).

\section{CONCLUSIONS}

In bitches pre-medicated with acepromazine, intravenous administration of the tiletamine-zolazepam combination at a dose of $2 \mathrm{mg} / \mathrm{kg} / \mathrm{h}$ does not produce satisfactory analgesia, does not prolong anesthesia recovery time, and does not interfere severely with cardiorespiratory function.

Conflict of interest statement.- The authors have no competing interests.

\section{REFERENCES}

Almeida E.M.P., Nunes N., Fantinatti A.P., Santos P.S.P., Bolzan A.A. \& Rezende M.L. 2000. Efeitos cardiorrespiratórios da associação de tiletamina/ zolazepam em cães (Canis familiaris) pré-tratados ou não pela acepromazina Braz. J. Vet. Res. Anim. Sci. 37(3):210-215. <http://dx.doi.org/10.1590/ S1413-95962000000300007>

Berry S.H. 2017. Anestésicos injetáveis, p.829-891. In: Grimm K.A., Lamont L.A., Tranquilli W.J., Greene S.A. \& Robertson S.A. (Eds), Lumb and Jones Anestesiologia e Analgesia Veterinária. 5a ed. Roca, Rio de Janeiro.

Cardoso F.T.S., Feitosa Júnior F.S., Diniz B.L.M., Lucena L.U. \& Silva Júnior J.R 2008. Neuroleptoanalgesia associada à anestesia epidural com lidocaína e xilazina em cutias (Dasyprocta aguti). Acta Scient. Vet. 36(2):149-154.

Duke T. 2013. Partial intravenous anesthesia in cats and dogs. Can. Vet. J. 54(3):276-282. <PMid:23997266>

Fantoni D.T. \& Cortopassi S.R.G. 2014. Medicação pré-anestésica, p.217-227. In: Fantoni D.T. \& Cortopassi S.R.G. (Eds), Anestesia em Cães e Gatos. $2^{\text {a }}$ ed. Roca, São Paulo.

Feitosa F.L.F. 2014. Exame físico geral ou de rotina, p.51-68. In: Feitosa F.L.F (Ed.), Semiologia Veterinária: a arte do diagnóstico. 6ª ed. Roca, São Paulo.

Figueiró M.R., Soares J.H.N., Ascoli F.O., Werre S. \& Segura I.A.G. 2016. Isoflurane MAC determination in dogs using three intensities of constant-current electrical stimulation. Vet. Anaesth. Analg. 43(5):464-471. <http://dx.doi. org/10.1111/vaa.12341> <PMid:27531057>

Filippi L.H. 2011. O Eletrocardiograma na Medicina Veterinária. Roca, São Paulo, p.69-88.

Goodwin J.K. 2002. Eletrocardiografia, p.39-65. In: Goodwin J.K. \& Tilley, L.P (Eds), Manual de Cardiologia para Cães e Gatos. 3a ed. Roca, São Paulo.

Haskins S.C. 2017. Monitoramento de pacientes anestesiados, p.270-353 In: Grimm K.A., Lamont L.A., Tranquilli W.J., Greene S.A. \& Robertson S.A. (Eds), Lumb and Jones Anestesiologia e Analgesia Veterinária. 5a ed. Roca, Rio de Janeiro.

Henrique F.V. 2018. Emprego da detomidina na contenção farmacológica e na anestesia intravenosa contínua com cetamina ou dextrocetamina em cadelas. Doctoral Dissertation, Universidade Federal de Campina Grande, Patos, PB. 107p.

Lacerda M.S., Sampaio R.L. \& Nunes T.C. 2010. Estudo hematológico e cardiorrespiratório em cadelas anestesiadas com cetamina-s/xilazina e tiletamina/zolazepam e submetidas a ovário-histerectomia. Biosci. J. 26(6):913-918. 
Lin H. C., Thurmon J.C., Benson G.J. \& Tranquilli W.J. 1993. Telazol--a review of its pharmacology and use in veterinary medicine. J. Vet. Pharmacol. Ther. 16(4):383-418. <http://dx.doi.org/10.1111/j.1365-2885.1993. tb00206.x><PMid:8126757>

Mannarino R. 2002. Determinação da taxa de infusão mínima de propofol e propofol associado a lidocaína em cães (Cannis familiaris). Master's Thesis, Universidade Estadual Paulista, Botucatu, SP. 128p.

Mello J.R.B. \& Cordeiro M.R.O. 2001. Avaliação da associação tiletaminazolazepam em cães de três diferentes faixas etárias. Arq. Fac. Vet. UFRGS 29(1):14-24.

Pereira T. 2008. Infusão contínua de remifentanil em cadelas pré-medicadas com levomepromazina e anestesiadas com tiletamina-zolazepam. Master's Thesis, Universidade Federal de Viçosa, Viçosa, MG. 56p.

Savvas I., Plevraki K., Raptopoulos D. \& Koutinas A.F. 2005. Blood gas and acidbase status during tiletamine/zolazepam anaesthesia in dogs. Vet. Anaesth. Analg. 32(2):94-100.<http://dx.doi.org/10.1111/j.1467-2995.2004.00177. x><PMid:15762914>
Valadão C.A.A. 2011. Anestesia dissociativa, p.73-84. In: Massone F. (Ed.), Anestesiologia Veterinária: farmacologia e técnicas. 6ª ed. Guanabara Koogan, Rio de Janeiro.

Valadão C.A.A. \& Pacchini C.E. 2001. Efeitos cardiorrespiratórios da tiletaminazolazepam em cães hipovolêmicos. Arq. Bras. Med. Vet. Zootec. 53(1):44-51. <http://dx.doi.org/10.1590/S0102-09352001000100007>

Vanova-Uhrikova I., Rauserova-Lexmaulova L., Rehakova K., Scheer P. \& Doubek J. 2017. Determination of reference intervals of acid-base parameters in clinically healthy dogs. J. Vet. Emerg. Crit. Care 27(3):325-332. <http:// dx.doi.org/10.1111/vec.12589> <PMid:28420042>

Veado J.C. 2001. Associação tiletamina-zolazepam na anestesia dissociativa de cães, protocolo original de utilização. Revta Bras. Saúde Prod. Anim. 1(1):19-26.

Yamashiro L.M., Floriano B.P., Pinho R.H., Wagatsuma J.T., Ferreira J.Z. \& Oliva V.N.L.S. 2015. Alteração do índice biespectral antes e após estimulação elétrica ou mecânica em cães anestesiados pelo isofluorano. Ciência Rural 45(9):1648-1653. <http://dx.doi.org/10.1590/0103-8478cr20141230> 